ZAKAR Ágnes

\title{
Magyarország és a skandináv országok közoktatása a PISA mérések tükrében
}

\section{Miért éppen Skandinávia?}

Skandinávia iránti mélyebb érdeklődésem már régi keletü. Elöször Dániában, még közvetlenül a rendszerváltás után, 1992-ben jártam, iskolai csoporttal, aztán dán gyerekeket fogadtunk iskolámban, Szentendrén. Nekem az tủnt fel akkor leginkább, hogy minden dán akivel csak találkoztam - kortól, foglalkozástól függetlenül, nagyon jól beszélt angolul. Abban az időben még a dán gyerekek markáns önbizalma is új volt számomra, ebben mára már felzárkóztak a magyar gyerekek is.

Rokoni kapcsolataimnak köszönhetően többször jártam már Svédországban is, ahol 90 éves nagybátyám él. Tőle tudtam meg azt, hogy a svédek milyen kiemelten foglalkoznak az idősekkel, házhoz járó, egészségügyi gondozást kap minden idős Svédországban, méghozzá ingyen, és ez a gondoskodás egész Skandináviára jellemző.

Egy további hatalmas élményemet 2013-ban Finnországban szereztem, ahol egy zenei rendezvényen vehettem részt Szentendre város képviseletében, testvérvárosunkban Uusikaupunkiban. Az ott eltöltött idő alatt nemcsak testvérvárosunk múzeumait, nevezetességeit ismerhettem meg, hanem a finnek életvitelét, számos hagyományát és természetesen a mienknél jóval magasabb életszínvonalát is.

Végül 2014 júniusában - nagy szerencsémre - egy a TÖOSZ (Települési Önkormányzatok Országos Szövetsége) által koordinált norvég - magyar projektben vehettem részt, melynek keretében Norvégiába is ellátogathattam. A projekt témája az esélyegyenlőség volt, címe: „Önkormányzati kapacitás-épités norvég-magyar együttmüködéssel”. Én az Oslótól 60 kmre levő Stangéba kerültem, egy farmokból álló kisvárosba, ahol módom volt az önkormányzati müködés mellett az oktatási rendszerbe is betekintenem. Ezek a személyes élmények a témához való kötődésemet erősítették.

\section{A skandináviai és a magyar oktatási rendszerek föbb jellegzetességei}

Az egyes országok közoktatási/köznevelési rendszereit számos szempont szerint lehet csoportosítani. E lehetőségek közül számomra a legszembetűnőbb az volt, hogy Európában is megkülönböztethetünk komprehenzív és szelektív iskolarendszereket, továbbá ezek is lehetnek erőteljesebben-, illetve kevésbé centralizáltak is. A komprehenziv iskolarendszer Skandináviára jellemző, általában két ciklusból áll: egy hosszú első szakaszból, mely 8-10 év, és egy rövid másodikból, mely 2-4 évig tart. Ez az iskolarendszer a korai szelekciót kívánja megakadályozni azzal, hogy tovább tartja együtt a tanulókat a hosszú alapozási periódusban. (Többen ${ }^{1}$ a komprehenzív, vagyis a szelekciómentes oktatásnak tulajdonítják a diákok jó tanulmányi eredményeit pl. Finnországban. Érvelésük szerint, ha az első, alapozó ciklus rövid - kb. 4-6 év, mint pl. Németországban, Máltán, Angliában - és az azt követő szakasz hosszú, az túl korai szelekciót eredményezhet.)

1 Kinyó László: A finn oktatás kutatás fejlesztése, Szeged, 2008.

http://www.oktatasikerekasztal.hu/hattertanulmanyok/09/kinyo_finn.pdf ,

Mihály Ildikó: Világraszóló oktatási sikerek és ami mögöttük van: A PISA-vizgálat finn eredményeiről . - In: Új pedagógiai szemle, ISSN 1215-1807, 2003. (53. évf.), 12. sz., 92-94. 
A magyar iskolarendszerben az egyértelmüen szelektív 4+8, a „köztes” 6+6, és az inkább integratív típusú $8+4$ struktúrájú képzés egyszerre van jelen. Ennek az egyidejüleg többféle belső szerkezetnek az együttélése azonban nemcsak a korai szelekció miatt, hanem az átjárhatóság szempontjából sem problémamentes. Melyik végül is az eredményesebb iskolarendszer-koncepció? Ha alkalmasnak fogadjuk el ennek kimutatására a PISA jelentések eredményeit, egyértelmü, hogy a szelektív rendszereknél sikeresebbek a komprehenzív, vagyis a szelekciómentes iskolarendszerek ${ }^{2}$.

Ha nemcsak az elveket, de a megvalósítási gyakorlatot is vizsgáljuk, azt kell észrevenni, hogy valamennyi skandináv ország oktatáspolitikájára jellemző az esélyegyenlőség valódi megteremtése az oktatásukban, az élethosszig tartó tanulás eszméjének magas kihasználtsága, a gyermekközpontúság, valamint az egyénre szabott oktatás mind a módszerek, mind a tanulókkal szemben támasztott követelmények terén.

Ha a skandináv országok oktatási rendszereit a tankötelezettség, a felnőtt oktatás, a finanszírozás, valamint a müködtetett intézménytípusok, az utóbbi évtizedekben bevezetett reformok és a szakképzés szempontjaiból részletesebben megvizsgáljuk (1. ábra), azt tapasztaljuk, hogy nemcsak egymáshoz állnak közel, de sok tekintetben hasonlóak a magyar oktatási rendszerhez is. Ilyen pl. a tankötelezettség felső korhatára, ahol, ha tekintetbe vesszük, hogy nálunk a tankötelezettség hosszúsága a következő tanévtől, tervezett 3 éves kortól kötelező óvodai ellátással 13 évre hosszabbodik, megállapíthatjuk, hogy hazánkban 3-4 évvel hosszabb ideig tart a gyermekek tankötelezettsége, mint a skandináv országokban. Ráadásul a skandináv országokban az óvodai nevelés-oktatás nem ingyenes, és Dánia kivételével nem is kötelezö. ${ }^{3}$

\begin{tabular}{|c|c|c|c|c|c|c|}
\hline & & & köteleze & & & \\
\hline & kötelezó & $\begin{array}{c}\text { Kezdete } \\
\text { (éves) }\end{array}$ & $\begin{array}{l}\text { Vége } \\
\text { (éves) }\end{array}$ & Szerkezet & (éves) & Sajátságok \\
\hline & & \multicolumn{3}{|c|}{ alapozó+ alsó käzépfok:9-10év } & $\begin{array}{c}\text { felsö } \\
\text { kōzépfok }\end{array}$ & \\
\hline Norvégia & nem & 6 & 16 & $7+3$ & $16-19$ & szakképzés \\
\hline Dánia & 1 év & 7 & 16 & $7+2$ & $16-19$ & $\begin{array}{l}\text { egyénre szabott } \\
\text { tanulás }\end{array}$ \\
\hline Svédország & nem & 7 & 16 & $6+3$ & $16-19$ & $\begin{array}{c}\text { sok nemzetiség } \\
\text { liberális }\end{array}$ \\
\hline \multirow[t]{3}{*}{ Finnország } & 1 év & 7 & 16 & $6+3$ & $16-19$ & komprehenziv \\
\hline & & \multicolumn{3}{|c|}{$\begin{array}{l}\text { általános iskola: alsó + felsö tagozat : } 8 \text { év } \\
4+4\end{array}$} & $\begin{array}{c}\text { 4/6/8 } \\
\text { osztályos } \\
\text { kōzépiskola }\end{array}$ & \\
\hline & \multirow[b]{2}{*}{$\begin{array}{l}3 \text { év } \\
/ 2015 /\end{array}$} & \multirow[b]{2}{*}{6} & \multirow[b]{2}{*}{16} & $4+4+4$ & $14-18$ & \multirow{2}{*}{$\begin{array}{l}\text { korai kezdés terve, } \\
\text { korai osztályozás, } \\
\text { tehetséggondozás }\end{array}$} \\
\hline Magyarország & & & & $\begin{array}{l}6+6 \\
4+8\end{array}$ & $\begin{array}{l}12-18 \\
10-18\end{array}$ & \\
\hline
\end{tabular}

1. ábra

2Önként adódik a kérdés, hogy ez a siker milyen módszerekkel, technikákkal és szervezési formák alkalmazásával hozható kapcsolatba? Jelen írás a továbbiakban erre a kérdésre is keresi az értelmesnek ható választ 3A többieknél csupán 1 iskola-előkészítő év ajánlott. Általában azonban ennek az évnek a kihasználtsága 90\% feletti pl. Finnországban. 
Eléggé nyilvánvaló, hogy a skandináv és a magyar oktatási rendszer eredményessége közötti különbséget elsősorban a gazdasági fejlettség, az oktatásra fordítható összegek relatív és abszolút nagyságai okozzák, köztudott, hogy Skandinávia országai - talán csak az óvodai nevelés kivételével - jóval többet költenek oktatásra, mint Magyarország (2. ábra). Ha azonban „közelebb” kerülünk a lehetséges okok elemzéséhez, észrevehető, hogy a magasabb összegü finanszírozás csak az érem egyik oldala, a sikerük nemcsak ezen múlik. A siker valódi kulcsa a ,skandináv gondolkodás”-ban rejlik, melyet az élet szinte minden területén önbizalom, mások elfogadása, ugyanakkor a nemzeti sajátságokra alapozott saját út és önálló építkezés jellemez. Több iskola munkájába is bepillanthattam, így több intézményvezetővel és számos tanár kollégával is beszéltem. Szinte minden ilyen alkalommal tetten érhető volt számomra egyfajta pozitív gondolkodás, amely értelemszerüen pozitívan befolyásolja az oktatás, nevelés eredményességét is. E mellett hatalmas előnyt biztosít számukra az is, hogy náluk ez a szelekciómentes és esélyegyenlöséget teremtő oktatás több évtizedes múltra tekint vissza, míg nálunk még mindkettő gyerekcipőben jár. (Magyarországon olyan nagyok az egyes régiók közötti társadalmi-gazdasági különbségek, hogy emellett szinte lehetetlennek tünik az Alaptörvényben egyébként helyesen megfogalmazott, mindenki számára elérhető, egységes és magas színvonalú közoktatás=köznevelés tényleges, gyakorlati megvalósítása.)

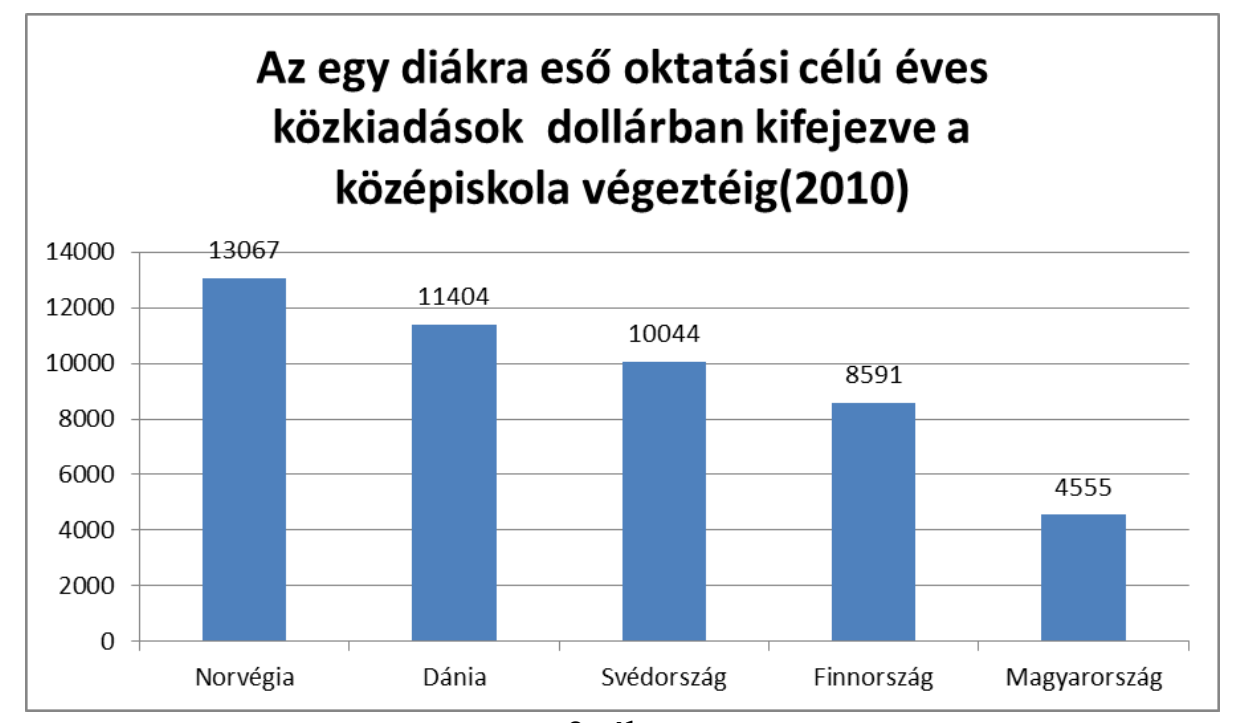

2. ábra

\section{Miröl árulkodnak a PISA jelentések?}

A skandináv közoktatás színvonalát és eredményességét sokan „skandináv csoda”-ként emlegetik. Kétségtelen, hogy az elért eredmények mögött gyakorlatilag szinte mindenütt magas szintü oktató-, nevelő munka áll. Mégis, szinte önként kínálja magát a kérdés: mennyire teljes körüen beszélhetünk erről a skandináv csodáról? Ha áttanulmányozzuk az oktatás eredményességét vizsgáló PISA jelentéseket, az a kép bontakozik ki előttünk, hogy az OECD országok között vezető helyen áll Finnország és előkelő helyet foglal el Dánia. A korábbi rosszabb eredmények után az oktatás megújítására nagy energiát fordító Norvégia oktatási eredményei javulni kezdtek, míg a svédországi eredmények ezeknél markánsan alacsonyabbnak mondhatók. Köztudott, hogy a skandináv országok eredményeihez képest a magyar oktatás teljesítményei jóval szerényebbek, így érdemes azt is elemezni, hogy mit tanulhatunk mi magyarok a skandináv népektől az oktatás terén. 


\section{A PISA jelentések eredményei 2000-2013. között}

A PISA (Programme for International Student Assesment) a világ legfejlettebb országait tömörítő OECD megbízásából készített felméréssorozat, amely a tizenöt éves diákok olvasásiszövegértési készségeit, matematikai és természettudományos kompetenciáját méri. Azon országok eredményeit méri, melyek a világ gazdasági összteljesítményének kb. kilenctizedét adják napjainkban. A PISA vizsgálat jellegzetessége, hogy nemcsak azzal foglalkozik, amit meg kellett volna tanulniuk a diákoknak, hanem azt is értékelni próbálja, hogy mit tudnak kezdeni a diákok az iskolában tanultakkal. Ezzel összhangban (és az összehasonlíthatóság biztosítása érdekében is) a feladatsorok nem lexikális tudást kérnek számon, hanem azt, hogy a középiskolások tudják-e a gyakorlatban alkalmazni a tanultakat. A vizsgálatot háromévente ismétlik meg, a rendszerhez Magyarország 1996-ban csatlakozott. 2013-ban a nyomtatott feladatsorok mellett számítógépes teszteket is kitöltettek a diákokkal szövegértésböl és matematikából.

A PISA 2000 jelentés ${ }^{4}$ sokak számára megdöbbentő eredményeket mutatott: Finnország diákjai messze kiemelkedtek az olvasás és szövegértés, de a matematika tantárgyi tudásukkal is a többi vizsgált ország közül. A kimagasló olvasási eredményeket többek között a szilárd alapú tanárképzéssel és a naprakész könyvtárszolgáltatással magyarázzák. ${ }^{5}$

\section{3. ábra ${ }^{6}$}

*A PISA jelentés a diákokat eredményeik alapján 5 szintbe sorolja, (1-es a legrosszabb, 5-ös a legjobb) a diagram a kijelölt országok eredményinek százalékos megoszlását mutatja olvasásszövegértés terén.

\section{A finn oktatási sikerek kulcsa}

Ma már tudjuk, hogy a finn sikernek, a kiváló eredménynek a hátterében a komprehenzív pedagógia áll, valamint a finn oktatási rendszerre jellemző következő sajátosságok:

- Az oktatás teljesen ingyenes;

- A középszintü oktatásban való részvétel is általános;

- Az oktatásirányítás centralizált, a végrehajtás azonban a helyi körülményekhez alkalmazkodik;

- Az oktatás minden szinten interaktív és kooperatív, áthatja a partnerség eszménye;

- A tanulók egyéni támogatást kapnak nemcsak a tanuláshoz, hanem szociális szükségleteik kielégítésében is;

- Az iskolai teljesítmények értékelése fejlődésorientált; nem használnak rangsorokat;

- Magasan kvalifikált, autonóm személyiségü pedagógusok oktatnak az iskolákban, akiknek az állam biztosítja az állandó szakmai továbbképzés hátterét anyagilag és folyamatos ajánlásokkal, továbbá az intézményvezető felelősségei közé tartozik a pedagógusok állandó fejlődésének biztosítása. Ezek a kötelező továbbképzések évente 3-5 naposak, az esetek többségében a tanév megkezdése előtt vagy a tanév végén kerítenek rá sort.

4Kinyó László: A finn oktatás kutatás fejlesztése, Szeged, 2008.

5Így pl. a finn diákok 44\%-a az olvasást jelölte meg kedvenc szabadidős tevékenységének, míg a legtöbb országban /Mexikó, Portugália kivételével/ ez az adat 20\% körül mozgott.

6A diagram nem az első öt helyezettet mutatja, csupán összehasonlításul szolgál. 
Van-e magyarázata kifejezetten az olvasás területén elért hatalmas eredményeknek? A finn oktatási szakemberek úgy gondolják, hogy igen; s ennek az alábbiakban magyarázatát is adják:

- A finn kultúra hagyományosan megbecsüli az olvasást;

- Nagyon magas színvonalú és sürün kiépített könyvtári hálózatukban jól felszerelt, modern gyüjteménnyel rendelkezö egységek vannak; s külön is kiemelendő a könyvtárak és az iskolák szakmai együttmüködése;

- Igen magas szintủ az anyák iskolázottsága;

- Finnországban semmilyen filmet nem szinkronizálnak, minden filmet az eredeti nyelven, és finn feliratozással vetítenek.

A nemek szerinti megoszlás viszont nem mutatott ilyen egyenletes színvonalat az olvasás terén, hiszen kiderült, hogy a finn fiúk jóval gyengébben olvasnak, mint a finn lányok, de még így is messze jobban, mint külföldi kortársaik. A finn fiúk olvasási felzárkóztatása érdekében mozgalmat indítottak. Olvasó Finnország - Reading Finnland címmel.

Meg is lett ennek az eredménye, a Pisa 2003-as jelentésben a fiúk teljesítménymutatói is javultak. Olvasás-szövegértésben megőrizték vezető helyüket (csak Dél-Korea tudott hasonló szinten teljesíteni), matematikából pedig még javították is. Az esélyegyenlőség és méltányosság alapelveinek érvényesülését támasztják alá, hogy a tanulók közötti teljesítménykülönbség csökkent. Matematikából a tanulók kis, mintegy 6 százaléka teljesített alul, szemben a többi országgal, ahol ez az arány $21 \%$ körül volt. Újabb kihívás, amire fel kell készülnie a finn oktatáspolitikának, az osztályok egyre változatosabb társadalmi összetétele. Más országokban, például a szomszédos Svédországban régóta élnek bevándorlók jelentős számban, de Finnországban viszonylag újdonságnak számít a nagyobb mértékü betelepülés. A bevándorlók integrációjára fókuszáló külön képzések fontosak lesznek, hiszen aggasztó tendenciát jelez, hogy a legújabb PISA-eredmények szerint a bevándorlók gyermekei szignifikánsan rosszabbul teljesítenek például matematikából finn társaiknál.

\section{4. ábra ${ }^{7}$}

*A PISA jelentés a diákokat eredményeik alapján öt szintbe sorolja, (1-es a legrosszabb, 5-ös a legjobb) a diagram a kijelölt országok eredményinek százalékos megoszlását mutatja olvasás-szövegértés terén.

** A PISA 2003 tapasztalatai mindenképpen azt mutatják: a finn oktatás helyes utat választott, és a gyakorlat által is visszaigazoltan, azóta is jó irányban fejlődik. Így például 2006-ban a közoktatás minden szintjén végrehajtottak változtatásokat, amelynek keretében a tankötelezettség időszakára vonatkozóan, tovább növelték az anyanyelvi és a matematikai óraszámokat, és újabb programokkal erösítették a tanulókkal közvetlenül foglalkozó pedagógusok továbbképzését is.

A 2012-es PISA- eredmények alapján összeállított rangsor élén Sanghaj áll - a kínai körzet 15 éves tanulói először 2009-ben vettek részt a felmérésen, és azonnal lekörözték az összes többi vizsgált országot matematikából, szövegértésből és természettudományból. A 2009-es PISA-kutatáshoz hasonlóan 2012-ben is az élmezőnyben végeztek a szingapúri, a hongkongi, a tajvani és a dél-koreai diákok. Az európai országok közül a liechtensteini, a svájci, a holland, az észt, a finn és a lengyel tanulók állnak a rangsor élén. Matematikából: Finnország

7A diagram nem az első öt helyezettet mutatja, csupán összehasonlításul szolgál. 
a 6., Magyarország a 28. helyen van. Vigasz lehet, hogy a svéd gyerekeknek sem erősségük a matematika: csak egy hellyel elöztek meg minket. Szövegértésböl még jobban végzett Finnország: a 3. helyen, Magyarország 22., Svédország utánunk következik. Természettudományokból a finnek a második legjobbak az OECD országok közül, Dánia, Norvégia jóval utánuk következik, mi a 23., míg Svédország a 27. helyen áll. Az Európai Bizottság értékelése szerint EU-szerte jelentős a lemaradás matematikából, biztatóbb viszont a helyzet a természettudományok és a szövegértés "úgy tủnik, Európa jó úton halad azon célkitüzése felé, hogy 2020-ra 15 százalék alá szorítsa a gyengén teljesítők arányát". ${ }^{8}$ A felmérés eredményei alapján 2009 óta tíz tagállam jelentős mértékben csökkenteni tudta a három alapkészség terén gyengén teljesítők arányát. Öt uniós országban, köztük Magyarországon, azonban emelkedett a gyenge teljesítményü diákok száma, más országok pedig vegyes eredménnyel szerepeltek. Az EU összességében valamivel jobb helyezést ért el, mint az Egyesült Államok, ám Japán mindkettőjüket messze maga mögé utasította.

\section{5. ábra ${ }^{9}$}

* A diagram az egyes országok átlagpontszámát mutatja, amit tanulóik a PISA feladatsorokon elértek a különböző kategóriákban.

\section{A siker záloga a motivált, elismert pedagógus}

Finnországban a tanárok szakmailag és anyagilag is nagyobb elismerésnek örvendenek, mint az OECD országok többségében. A tanári szakma finnországi presztízsét jól mutatja, hogy az egyetemen akár huszonötszörös túljelentkezés sem ritka a tanári és tanítói szakokra. ${ }^{10} \mathrm{~A}$ tanári képzés egyike a legnépszerübb egyetemi programoknak az orvosi és jogi tanulmányok mellett. Több körben vizsgálják a pedagógus szakra jelentkezők alkalmasságát, kiválasztásuknál fontos szempont, hogy a tanárjelöltek kreatívan és sokoldalúan tudjanak órát tervezni és vezetni, csak a jelentkezők 5\%-át veszik fel. A szülői bizalom is rég keletü, a tanítókat a 19-20. század fordulóján metaforikusan a nép gyertyáinak is nevezték. ${ }^{11}$ Társadalmilag ma is az egyik legmegbecsültebb pálya Finnországban a tanítói, és azon belül is az anyanyelvet tanítók elismertsége kiemelkedő. A finn pedagógusok anyagi megbecsülését jelzi az OECD átlagnál magasabb kereset, ráadásul a pedagógusbérezés rugalmas, figyelembe veszik az egyéni kompetenciákat.

A pedagógusképzést Finnországban az 1970-es években egységessé tették, a pedagógiai tanulmányokat megerősítették, megszüntették az alsóbb és felsőbb osztályokban tanítók közötti szintkülönbséget. 1971 óta a tanítókat és a tanárokat egyaránt színvonalas egyetemi képzésben részesítik, az óvodapedagógus kivételével minden tanárnak mesterképzéses diplomája (MA) van, legyenek 7-12 éves korosztállyal foglalkozó általános tanítók vagy 1316 évesekkel dolgozó szaktanárok. A tanítóképzés során a neveléstudományok jelentik a főszakot, és e mellett 60 kredites modulokban sajátítják el a szaktantárgyakat, amelyeket tanítani fognak, de a fó hangsúly a neveléstudományon van. Finnországban a pedagógusképzésnek fontos része a gyakorlati oktatás, mely az állam által fenntartott 13

8PISA jelentés 2012

9A diagram nem az első hét helyezettet mutatja, csupán összehasonlításul szolgál. 10Finn tanárképzés 1. Nyelv és Tudomány Szabó Tamás Péter: Ahol divat tanárnak lenniwww.nyest.hu/hirek/ahol-divat-tanarnak-lenni 2015. febr. 5. - Finn tanárképzés 11Finn tanárképzés 1. Nyelv és Tudomány Szabó Tamás Péter: Ahol divat tanárnak lenniwww.nyest.hu/hirek/ahol-divat-tanarnak-lenni 2015. febr. 5. - Finn tanárképzés 1. 
egyetemekkel szoros szakmai kapcsolatban álló gyakorlóiskolában történik. A gyakorlóiskola tanárai és az egyetemi oktatók szorosan együttmüködnek a pedagógusképzésben. Az oktatás fő jellemzője az oldott, kreatív oktatási környezet és a diákközpontú oktatás.

\section{Összegzés}

A PISA jelentések oktatásról szóló számadatai több kutató, így Benedek Mihály szerint is ${ }^{12}$ pontosan leképezik az adott társadalom gazdasági, szellemi és önértékelési állapotát. Amíg a jó finn eredmények mögött nincsenek szélsőségek, mert a finneknek egyrészt sikerült az ország bármely szegletében elérni gyakorlatilag ugyanazt a magas színvonalú oktatást, másrészt szinte mindenütt viszonylag egyenletesen magas a tanulók által elért átlagteljesítmény, addig a középmezőnyben végzett országok között -ilyenek pl. a lengyel vagy a magyar tanulók eredményei - egyszerre jelennek meg a nagyon jó és a nagyon gyenge teljesítmények. (A jó eredmények mögött többek között ott állnak az elit iskolák és egyes kiemelten magas színvonalon teljesítő intézmények, a rossz eredmények mögött a hátrányos helyzetü, oktatási nehézségekkel is küzdő régiók iskoláinak kudarcai, és az, hogy felzárkóztatás terén is van még mit tennünk. Az új Nemzeti Köznevelési Törvény helyesen órakeretet biztosít a tehetséggondozás mellett a felzárkóztatásra is. Csak élni kellene vele! Ez így magyarázatot is nyújtana sok mindenre, de mit keres a középmezőnyben Svédország, ahol a szemlélet, oktatási rendszer, az oktatásra fordított összegek, energia, célok, életszínvonal a finnekéhez hasonló. Itt miért nem müködik a „skandináv modell’? Az utolsó PISA jelentés óta napi sajtótéma a rosszul teljesítő svéd oktatási rendszer, és annak kudarcainak feltételezett okaival kapcsolatos elemzések. Mostanság Svédországban a legtöbb helyen a bevándorlók integrálása jelenti a legnagyobb kihívást az oktatásban. Vannak olyan lakótelepek - pl. Stockholm közelében Taby - ahol az iskolákban a bevándorlók gyermekeinek aránya akár a $90 \%$-ot is elérheti. A svédek manapság nem túl pozitívan értékelik sem az oktatási rendszerüket, sem annak eredményességét. ${ }^{13}$

6. ábra Egy sokszínü svéd iskola

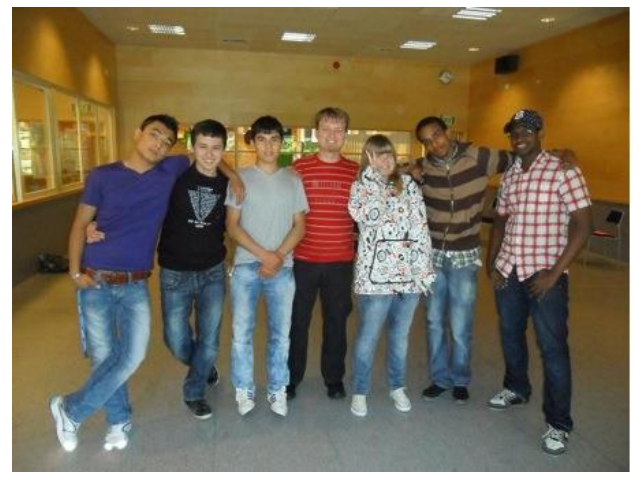

\section{Ami a PISA jelentés számadatai mögött áll}

Mint ahogyan azt már fentebb is említettük, a középmezőnyben teljesítő országok számadatainak szélső értékei, - vagyis a jó és rossz eredmények közötti különbség sokkal nagyobb, mint az élmezőny országaié, sőt, a 2000 és 2012 közötti időszakot vizsgálva az is látható, hogy ez a különbség azóta még növekedett is. Mi áll e mögött az elmondottakon túl? 
- A jól teljesítő országoknál megfigyelhető a gyengén teljesítő diákok felelős, konstruktív kezelése. Nem megbuktatják vagy eltanácsolják őket, hanem az adott oktatási intézményen belül, egyénre szabott program alapján foglalkoznak velük.

- Az iskolák között azokban az országokban nagyobbak a teljesítménkülönbségek, ahol már a korai életkorban - pl. a beiskolázásnál - merev szelekciós szempontok müködnek.

- A jól teljesítő országoknál heterogén összetételü tanulócsoportokat képeznek, és általában is egyénre szabott tanulási tervekkel dolgoznak. Számos tanterven és tanórán kívüli tevékenységet is kínálnak a tanulóknak, és jelentősebb intézményi differenciálást csak a felsőbb évfolyamokban vezetnek be, ha egyáltalán bevezetnek.

A finnek kiváló PISA eredményei mögött tudatosan és sikeresen felépített oktatási modellről van szó, amelyben minden szereplő a tudása legjavát nyújtja. ${ }^{14}$ A kötelező kilencévi iskoláztatás ideje alatt Finnországban alig több az iskolaelhagyók aránya, mint 1 százalék, ami messze a legjobb arány a világon, de az iskolaelhagyóknak több mint a fele később a felnőtt oktatás keretében befejezi tanulmányait.

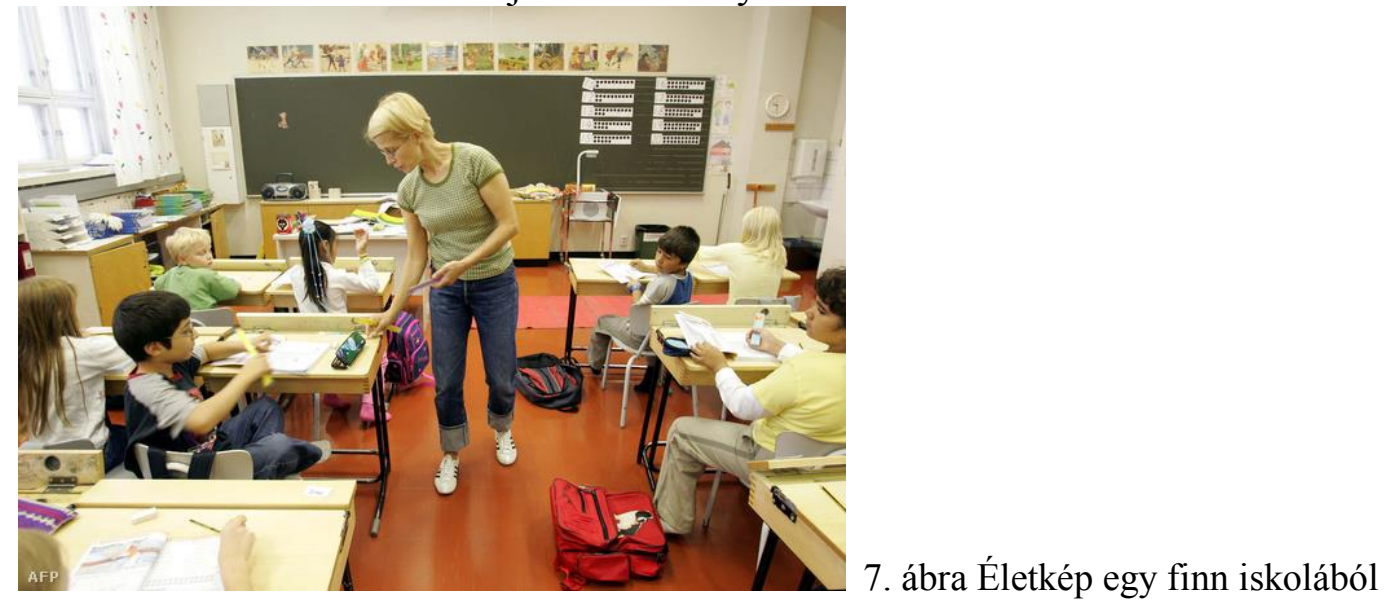

\section{A ,skandináv modell” üzenete}

A sikeres skandináv oktatáspolitikának főbb szegmenseiről már szóltam, de ha két legfontosabb, a magyar oktatási rendszerben is megvalósítható oktatáspolitikai intézkedést kiemelhetek, az a mindenki számára biztosított csaknem azonos esély és az elismert, motivált, képzett tanárok alkalmazása. Bár a finn és a magyar iskolastruktúra jelentősen különbözik egymástól, az oktatásirányítás rendszerében több hasonlóság is van. A hasonlóságok között említhető még, hogy Finnországban és Magyarországon is a nemzeti alaptanterv keretrendszerü dokumentum, amely alapján az iskolák maguk alakítják ki helyi tanterveiket, és mindkét országban megszüntették a külső ellenőrzési - értékelési rendszert. Utóbbit nálunk sajnos ideje korán, úgyhogy ezen a téren vissza kellett térnünk a külső ellenőrzéshez, szemben a finnekkel, ahol ez az intézkedés sikeresnek mondható. Az új Nemzeti Köznevelési Törvény megjelenésével hasonló lett a tankötelezettség korhatára is (16 éves korig) mind a két országban. A rendszerszintü hasonlóságok ismeretében felmerülhet a kérdés, hogy a két oktatási rendszer között hogyan jöhettek létre ekkora teljesítménybeli, eredményességbeli különbségek. Szakemberek álláspontja szerint a különbségek okai legáltalánosabban az oktatáspolitikai döntések időzitésében keresendők, mint az előbb említett

14Benedek Mihály: A „finn csoda” és ami mögötte van. Új pedagógiai Szemle 2005. 
túl hamar megszüntetett magyarországi ellenörzési, visszacsatolási szakfelügyeleti rendszernél. Míg nálunk minden előkészítés nélkül 1985-ben szüntették meg az ellenőrzési rendszert, addig a finneknél ezt a döntést hosszú, évekig tartó előkészítés és társadalmi párbeszéd előzte meg, és együtt járt egy új önellenőrzési rendszer kiépítésével is.

Jelen írás befejezéseként Benedek Mihály ${ }^{15}$ gondolatát idézem. „Talán nem is a rendszer a lényeges, sokkal inkább a konferencia üzenete, amely egyben a siker záloga is: szeretni kell a gyerekeket, meg kell becsülni a pedagógusokat, mindenkinek esélyt kell adni a tanulásra, az élethosszig tartó tanulásra. Az oktatási környezetnek befogadónak és nem kirekesztőnek kell lennie, nem a folytonos számonkérés, a bizonyítványok a fontosak, hanem a fejlődés, nem a teljesítmény abszolút értéke számít, hanem az, hogy a gyerek szeresse, amit csinál."

Ha ez a siker záloga, akkor bizony van még mit tennünk!

\section{Felhasznált irodalom}

A finn PISA-csoda oka . - In: Élet és tudomány, ISSN 0013-6077 , 2010. (65. évf.), 31. sz., 963964. p.

Balaskó Attila: Minőségfejlesztés a dán oktatási rendszerben, 2000. - In: Szakoktatás, 0273-5338. 50/1. (2000)

Balázs Éva: Jelentés a magyar közoktatásról . — Budapest : OFI, 2011( : Crew Ny.). — 591 p.

Balázs Év(szerk): Oktatás és decentralizáció Közép-Európában : tanulmánykötet . — Budapest : OKKER K. 2000.

Balázs Péter: EU-csatlakozás 2004 _ — Budapest : Magyar Köztársaság Külügyminisztériuma, 2003. $159 \mathrm{p}$.

Benedek Mihály: A "finn csoda" - és ami mögötte van - PISA-konferencia Helsinkiben, 2005. március 14-16. . - In: Új pedagógiai szemle, ISSN 1215-1807 , 2005. (55. évf.), 4. sz., 108112.

Berényi Eszter : Iskolarend : kiváltság és különbségtétel a közoktatásban — Budapest : Gondolat, 2008.

Bernáth József : Közoktatástan . — Pécs : JPTE, 1997.

Csapó Benő - Molnár Gyöngyvér - Kinyó László: A magyar oktatási rendszer szelektivitása a nemzetközi összehasonlító vizsgálatok eredményeinek tükrében . - In: Iskolakultúra, ISSN 1215-5233 , 2009. (19. évf.), 3-4. sz., 3-13. p.

Drabancz M. Róbert (1965-) (szerk. ) : Oktatás és politika : tanulási segédlet az oktatáspolitika tanulmányozásához . - Nyíregyháza : Krúdy, 2009 (Nyíregyháza : Krúdy Ny.). — 320 p.

Education from Kindergarten to Adult Education - Norwegian Ministry of Education and Research 2008. /Oktatási rendszer az óvodától a felnőtt oktatásig/

Eide, Kjell: The Future of European Education as Seen from the North (Az európai oktatás jövője északi szemszögből) (/angol nyelvü) Folyóirat: Comparative Education, 1992. No.1. 9-17. p.

Forgács András: Az Európai Unió és az oktatás . — Budapest : Press Publica, 2003

Fürtön Tamás: A skandináv oktatási modell: a norvég szakoktatási, képzési, értékelési szerkezet In: Szakoktatás: az Országos Pedagógiai Intézet Szakképzés Igazgatóságának pedagógiai folyóirata, ISSN 0237-5338 , 2008. (57. évf. ) 3 sz. 18-24. p

Halász Gábor: Az oktatás az Európai Unióban : tanulás és együttmüködés . — Budapest : Ú-M-K, 2012

Halász Gábor: Jelentés a magyar közoktatásról 2003., 2006. — Budapest : Országos Közoktatási Intézet, 2003.

15Benedek Mihály: A „finn csoda” és ami mögötte van. Új pedagógiai Szemle 2005. 
Harangi László: A dán felnőttoktatás rendszere . - In: Kultúra és közösség, ISSN 0133-2597, 2010. (1.(14) évf.), 4. sz., 93-131. p. http://www.kulturaeskozosseg.hu/pdf/2010/4/kek_2010_4_14.pdf

Kinyó László: A finn oktatás kutatás fejlesztése, Szeged, 2008. http://www.oktatasikerekasztal.hu/hattertanulmanyok/09/kinyo finn.pdf

Kron, Friedrich W. : Pedagógia . - Budapest : Osiris, 2003

Lukács Péter (1948-) (szerk. ) : Oktatáspolitika : válogatás a hazai szakirodalomból . — Budapest : Felsőokt. Kutint. : Új Mandátum, 2004.

Lundström, Karin: Speciális oktatás Svédországban : [Fordítás] ford. Illyés Sándor Megjelenés: 1970

Martis Zsombor: Egy skandináv út - Dánia oktatási rendszere (könyvanalitika) Wilheimné Ádám Ibolya: Dánia, oktatási rendszer ; Leonardo da Vinci program ; mezőgazdasági szakképzés ; modulrendszerü képzés ; modulrendszerü tervezés, Szakoktatás, 50/1. (2000)

Mészáros István: Neveléstörténet : Bevezetés a pedagógia és az iskoláztatás történetébe . Budapest : Osiris,

Mezei Gyula-Benedek András: A közoktatás rendszere [változó iskolarendszerek, felügyelet, szakértői munka] / Mezei Gyula. - 7. átd. kiad. utánny. (2005)

Miből áll a skandináv odell?(http://mandiner.hu/cikk/20140401_mibol_all_a_skandinav_modell)

Mihály Ildikó: Iskolarendszerek Európában / Finnországi mozaikok/ Szakoktatás : az Országos Pedagógiai Intézet Szakképzési Igazgatóságának pedagógiai folyóirata.- 54. évf. 3. sz. I 2004 . 6-17. p.

Mihály Ildikó: Világraszóló oktatási sikerek és ami mögöttük van: A PISA-vizgálat finn eredményeiről . - In: Új pedagógiai szemle, ISSN 1215-1807 , 2003. (53. évf.), 12. sz., 9294.

Milyen ma a finn iskolarendszer? (http://www.ofi.hu/tudastar/iskolarendszerek/milyen-ma-finn)

Németh Ágnes: Finnország oktatási rendszere/. - Budapest : OPKM, 1985 . 49 p. : ill. ; 21 cm. (Országos Pedagógiai Könyvtár és Múzeum kiadványai, Iskolarendszerek)

Németh Szilvia: Tényekre alapozott oktatás egy finn integrált nevelést folytató alsó-középfokú intézményben Esettanulmány, Vesala, Helsinki 2011.

Ormándi János : Összehasonlító pedagógia : Jegyzet a felsőoktatás és a pedagógus-továbbképzés résztvevői számára . - Gyula : APC-Stúdió, 2006

Ormándi János: Nevelés Dániában. Módszertani Közlemények, 1994. 34/2. szám 103-106.

Pénzes Éva: A finn csoda magyar szemmel - Tanulmányút a finnországi Ouluban . - In: Gyógypedagógiai szemle, ISSN 0133-1108 , 2009. (37. évf.), 4. sz., 284-287. p.

Perjés István: Gyakorlatiasság, kreativitás és józan ész. A finn oktatás paradoxonjai? . - In: Új pedagógiai szemle, ISSN 1215-1807 , 2014. (64. évf.), 1-2. sz., 5-14. p.

Pintér Róbert: A finn csoda titka : Castels, Manuel - Himanen, Pekka (2002): The information society and the welfare state - The Finnish model . - In: Információs társadalom, ISSN 1587-8694 , 2006. (6. évf.), 3. sz., 152-164. p.

PISA jelentések /2000, 2003, 2012. évi eredmények

Sahlberg, Pasi / A finn példa : mit tanulhat a világ a finnországi oktatási rendszer reformjából? / ford. Fazekas Dóra. - Budapest : Nemzedékek Tudása Kiadó, 2013

Setényi János: A svéd modell : mítosz és valóság. Oktatáskutató Intézet,Budapest 1990.

Szabó Tamás Péter: Ahol divat tanárnak lenni. www.nyest.hu/hirek/ahol-divat-tanarnak-lenniFinn tanárképzés 1. Nyelv és Tudomány, 2015. febr. 5.

Torgyik Judit (szerk): Oktatási rendszerek Európában, Budapest : Krónika Nova, 2009, Wichmann, Lise: Dán tapasztalatok a felnőttoktatásban, Szakoktatás, 0273-5338. 45/4. (1995)

Wilheimné Ádám Ibolya: A projekt-módszer alkalmazása a dán oktatási rendszerben Szakoktatás, 50/1. (2000) 